\title{
Identification of Imipenem-Resistant Genes in Acinetobacter baumannii Isolated from Baghdad Hospitals
}

Nadheema Hammood Hussein1, Harith Jabbar Fahad Al-Mathkhury ${ }^{2 *}$ and Majeed Arsheed Sabbah ${ }^{3}$

${ }^{1}$ Department of Biology, College of Science, Al-Mustansiryah University, Iraq

${ }^{2}$ Department of Biology, College of Science, University of Baghdad, Iraq

${ }^{3}$ Biotechnology Research Centre, Al-Nahrain University, Baghdad, Iraq

\begin{abstract}
Imipenem-resistant Acinetobacter baumannii (IRAB) represents one of the important causing agents of nosocomial infections especially in immunocompromised and Intensive Care Units (ICUs) patients. The aim of this work was to identify the Imipenem-Resistant genes in Acinetobacter baumannii isolated from Baghdad hospitals. Among 128 A. baumannii isolates, 67 isolates (58.26\%) were resistant to imipenem and meropenem. Four genes for imipenem resistance (blaOXA-23 like, blaOXA-24 like, blaOXA-51like and blaOXA-58 like) were amplified and sequenced. The presence of blaOXA-23-like genes in $91.03 \%$ of IRAB isolates indicated that the blaOXA-23-like genes are the predominant mechanism for imipenem resistance in our isolates. Sequencing of PCR products showed the presence of new OXA-genes in local $A$. baumannii isolates including: OXA-207, OXA-239 and OXA-229 among the genes of OXA-24-like, OXA-23-like and OXA-58-like genes, respectively. In conclusion, this study identifies the genes responsible for the imipenem resistance in Baghdad which is important to understand the imipenem resistance and to suggest plans for treatment of patients in future.
\end{abstract}

Keywords: Acinetobacter baumannii; Beta lactamases; Rep-pcr; IRAB; Imipenem

\section{Introduction}

During the last two decades A. baumannii became clinically important pathogen due to its capability for outbreaks and resistance to most antibiotics including carbapenems [1]. The outbreak of $A$. baumannii associated with United States military operations in Iraq generated special interest in this organism [2]. The features of $A$. bumanii for resistance to most available antibiotics and environmental stress enable the bacteria to persist in hospitals and epidemic spread [3]. Several studies reported that carbapenem-resistant A. baumannii strains have been now emerged around the world [4-6]. This resistance is principally caused by the production of carbapenemases [7]. Carbapenem-hydrolysing class D $\beta$-lactamases (CHDLs) are the most often reported mechanisms of carbapenem resistance in A. baumannii and four groups of CHDLs have been identified inimipenem-resistant A. baumannii, including intrinsic and chromosomally located OXA51-like $\beta$-lactamases and acquired OXA-23-like, OXA-24-like and OXA-58-like $\beta$-lactamases $[8,9]$.

Till now, no study has been performed in Iraq identification of Imipenem-Resistant A. baumannii genes among Iraqi patients. Therefore, this study aimed to investigate the Imipenem-Resistant bla-OXA $\beta$-lactamases genes in A. baumannii among patients in four hospitals in Baghdad, Iraq.

\section{Materials and Methods}

\section{Isolation and processing of samples}

One thousand and nine hundreds specimens comprising, urine, wounds, burns, blood and sputum, were collected in sterilized containers from patients attending four hospitals in Baghdad-Medical city including: Baghdad Teaching Hospital, the Martyr Gazi Al-Hariry Hospital, Welfare Teaching Hospital and the Burn Specialist Hospital.

All bacterial isolates were identified by routine morphological, biochemical carried out according to Forbes et al. [10]. Additionally, identification was confirmed by api20E (bioMerieux, France).
Furthermore, species identification of Acinetobacter baumannii isolates was performed by Polymerase chain reaction (PCR) to detect blaOXA-51-Like genes [11,12]. The results of bacterial identification were published separately [13].

Antibiotic susceptibility was done for 20 antibiotics available in the market. Disc agar diffusion test was performed according to the KirbyBauer standardized antimicrobial susceptibility single disc method [14]. Serial dilution agar method was applied for the determination of minimal inhibitory concentrations (MICs) to Imipenem and Meropenem [15]. Escherichia coli (E. coli ATCC 25922) was used as a quality control in susceptibility determination.

An isolate was interpreted as susceptible, intermediate, or resistant to a particular antibiotic by comparison with standards inhibition zones or MIC break point according to Clinical Laboratories Standards Institute (CLSI) [16]

\section{Extraction of genomic DNA}

DNA was extracted from A. baumannii isolates using a commercial purification system (Genomic DNA Mini Kit, Geneaid, Thailand), then the DNA concentration and purity were determined [17].

\section{Multiplex PCR assay}

Multiplex PCR was achieved to amplify four carbapenem resistance genes (oxacillinases) including: bla OXA-51-Like genes (which is also

*Corresponding author: Harith Jabbar Fahad Al-Mathkhury, Department of Biology, College of Science, University of Baghdad, Iraq, Tel: 7712277025 E-mail: harithfahad@scbaghdad.com

Received September 05, 2014; Accepted November 20, 2014; Published November 22, 2014

Citation: Hussein NH, Al-Mathkhury HJF, Sabbah MA (2014) Identification of Imipenem-Resistant genes in Acinetobacter baumannii Isolated from Baghdad Hospitals. J Med Microb Diagn 3: 170. doi:10.4172/2161-0703.1000170

Copyright: (c) 2014 Hussein NH, et al. This is an open-access article distributed under the terms of the Creative Commons Attribution License, which permits unrestricted use, distribution, and reproduction in any medium, provided the original author and source are credited. 
Citation: Hussein NH, Al-Mathkhury HJF, Sabbah MA (2014) Identification of Imipenem-Resistant genes in Acinetobacter baumannii Isolated from Baghdad Hospitals. J Med Microb Diagn 3: 170. doi:10.4172/2161-0703.1000170

Page 2 of 3

adopted for the identification of isolates to species level) [11,12], bla OXA-23-Like genes, bla OXA-24-Like genes and bla OXA-58-Like genes using the listed primers in Table 1 (primers synthesized by Alpha DNA, Canada). Multiplex PCR was optimized using the PCR premix (Accupower, bioneer-Korea).

\section{Sequencing of PCR products}

Multiplex PCR products for blaOXA-23 like, blaOXA-24like, blaOXA-51 like and blaOXA-58 like genes were detected by agarose gel electrophoresis and purified by Gel/ PCR DNA Fragment Extraction Kit (Geneaid, Thailand), and then the sequencing was carried out using the ABI capillary system (Macrogen, Korea). PCR products were subjected to direct sequencing. DNA sequences were analysed and similarity searches were carried out with the Basic Local Alignment Search Tool (BLAST) in National Centre for Biotechnology Information (NCBI) website (http://www.ncbi.nlm.nih.gov).

\section{Results and Discussion}

\section{Antibiotic susceptibility}

Data published previously [14] indicated a high level resistance of A. baumannii clinical isolates to most of the antibiotics under test. The MIC values for imipenem and meropenem resistant isolates ranged from $16 \mu \mathrm{g} / \mathrm{ml}$ to $512 \mu \mathrm{g} / \mathrm{ml}$.

Detection of carbapenem resistance genes (oxacillinases) by multiplex polymerase chain reaction (PCR)

The results of resistance genes amplification presented in Figure 1

\begin{tabular}{|c|c|c|c|}
\hline OXA-genes & Primer name & Sequence & $\begin{array}{l}\text { Product } \\
\text { size }\end{array}$ \\
\hline \multirow[t]{2}{*}{ blaOXA-51-Like } & OXA-51-Like-F & 5'-TAATGCTTTGATCGGCCTTG-3' & \multirow[t]{2}{*}{$353 \mathrm{bp}$} \\
\hline & OXA-51-Like-R & 5'-TGGATTGCACTTCATCTTGG-3' & \\
\hline \multirow[t]{2}{*}{ blaOXA-23-Like } & OXA-23-Like-F & 5'-GATCGGATTGGAGAACCAGA-3' & \multirow[t]{2}{*}{$501 \mathrm{bp}$} \\
\hline & OXA-23-ike- $R$ & 5'-ATTTCTGACCGCATTTCCAT-3' & \\
\hline \multirow[t]{2}{*}{ blaOXA-24-Like } & OXA-24-Like-F & 5'-GGTTAGTTGGCCCССTTAAA-3' & \multirow[t]{2}{*}{$246 \mathrm{bp}$} \\
\hline & OXA-24-Like-R & 5'-AGTTGAGCGAAAAGGGGATT-3' & \\
\hline \multirow[t]{2}{*}{ blaOXA-58-Like } & OXA-58-Like-F & 5'-AAGTATTGGGGCTTGTGCTG-3' & \multirow[t]{2}{*}{$599 \mathrm{bp}$} \\
\hline & OXA-58-Like-R & 5'-CСССTCTGCGCTCTACATAC-3' & \\
\hline
\end{tabular}

Table 1: Primers used for multiplex PCR amplification of $A$. baumannii oxacillinases genes.

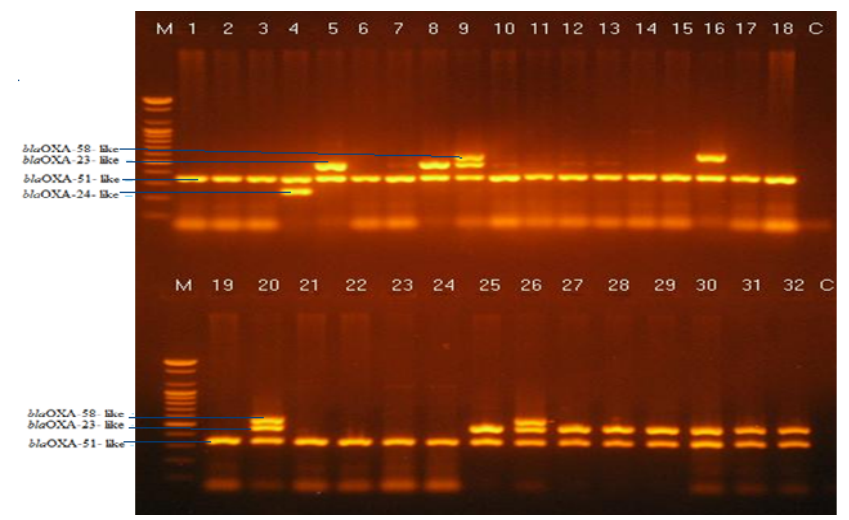

Figure 1: Ethedium bromide stained agarose gel (1.5\%) electrophoresis of PCR products for the resistance genes blaOXA-51-like, blaOXA-51-like, blaOXA-23-like blaOXA-51-like and blaOXA-58-like. Lane M, 100 bp DNA ladder; lanes 1-32, Acinetobacter baumannii1-128 isolates; lane C, Negative control (had all PCR mixture including water instead of DNA template).

\begin{tabular}{|c|c|c|}
\hline blaOXA type & $\begin{array}{c}\text { Imipenem-resistant } \\
\text { A. baumannii }(\mathbf{n = 7 8})\end{array}$ & $\begin{array}{c}\text { Imipenem-sensitive } \\
\text { A. baumannii (n=50) }\end{array}$ \\
\hline blaOXA-51-like alone & 2 & 48 \\
\hline $\begin{array}{c}\text { blaOXA-51-like plus blaOXA-23-like } \\
\text { blaOXA-51-like plus blaOXA-23-like } \\
\text { and blaOXA-58-like }\end{array}$ & 61 & $\mathrm{ND}$ \\
\hline $\begin{array}{c}\text { blaOXA-51-like plus blaOXA-24-like } \\
\text { blaOXA-51-like plus blaOXA-58-like }\end{array}$ & 10 & $\mathrm{ND}$ \\
\hline Total & 5 & $\mathrm{ND}$ \\
\hline
\end{tabular}

ND=Not Detected; $P<0.05$

Table 2: Distribution of blaOXA genes among $A$. baumannii isolates.

and Table 2 illustrate the presence of blaOXA-51-like genes in all 128 (100\%) A. baumannii clinical and environmental isolates (regardless to imipenem suceptibility). The blaOXA-51-like genes were reported to be highly specific for the identification of A. baumannii at the species level $[18,19]$. The blaOXA-23-like genes present in $91.03 \%$ of IRAB which indicated its responsibility for the dominant carbapenem resistance gene in the local A. baumannii isolates. Nevertheless, similar findings were reported in countries other than Iraq, such as Bulgaria, China, Brazil, Afghanistan [20], Korea, Singapore and Thailand [21].

A study carried out by Hujer et al. [22] demonstrated that $97 \%$ of A. baumannii strains (isolated from military and civilian personnel injured in the Iraq/Kuwait region during Operations in Iraq have blaOXA-69-like gene (a member of blaOXA-51-like genes). blaOXA23-like genes detected in $11 \%$ of those strains and the blaOXA-58-like genes were detected in $12 \%$ of the isolates; whereas blaOXA-24-like genes were not detected at all. This may specify the non-relatedness between Hujer's isolates and those isolated in the present study.

It is markedly noticed that two (4\%) out of fifty imipenem sensitive A. baumannii environmental isolates harboured blaOXA-58-like genes in addition to blaOXA-51-like genes. Although these two isolates have blaOXA-58-like genes, no resistance was developed phenotypically. Such finding could be assigned to the absence of the insertion sequence ISAba1 upstream blaOXA-58-like genes. Corvec et al. [23] and Zhong et al. [24] stated that in A. baumannii the OXA genes are expressed when the insertion sequence ISAba1 inserts upstream of the gene where it provides a promoter for gene expression.

\section{Sequencing of multiplex PCR products}

Results revealed that GenBank accession numbers for the nucleotide sequences of the blaOXA-51-like, blaOXA-58-like, blaOXA-23-like and blaOXA-24-like genes fragments are JX305928, JQ409994, JQ343841 and JX310716, respectively. In OXA-51-like genes sequencing we found some differences in the nucleotides of our query and the subject in position 5, 11,21,35, 40,111,247, 268, 289 and 316 of the subject. In the case of OXA-58-like gene the differences are 315, $323,324,342,355,519,522,531,532$ and 537 of the subject. In regard to OXA-23-like gene the differences are 127, 131, 145, 148, 158, 164, $167,186,207,241,250$ and 256 of the subject. Regarding OXA-24-like gene the differences are 195,198, 204, 207, 210 and 215 of the subject.

Interestingly, OXA-207 gene was found among the OXA-24-like genes in local A. baumannii isolates; this gene (OXA-207) has not been previously reported in A. baumannii strains. Nevertheless, it was mentioned to be found in other species of the genus Acinetobacter.

In this study we identify the sequences of Imipenem-resistance genes in our local A. bumannii isolates; this will improve the management and control of this pathogen in Baghdad hospitals. 
Citation: Hussein NH, Al-Mathkhury HJF, Sabbah MA (2014) Identification of Imipenem-Resistant genes in Acinetobacter baumannii Isolated from Baghdad Hospitals. J Med Microb Diagn 3: 170. doi:10.4172/2161-0703.1000170

\section{References}

1. Karah N, Sundsfjord A, Towner K, Samuelsen $\varnothing$ (2012) Insights into the global molecular epidemiology of carbapenem non-susceptible clones of Acinetobacter baumannii. Drug Resist Update 15: 237-247.

2. Perez F, Endimiani A, Ray AJ (2010) Carbapenem-resistant Acinetobacter baumanniiand Klebsiella pneumoniae across a hospital system, impact of postacute care facilities on dissemination. J Antimicrob Chemother 65: 1807-1818.

3. Visca P, Seifert H, Towner KJ (2011) Acinetobacter infection--an emerging threat to human health. IUBMB Life 63: 1048-1054.

4. Liakopoulos A, Miriagou V, Katsifas EA, Karagouni AD, Daikos GL, et al. (2012) Identification of OXA-23-producing Acinetobacter baumannii in Greece, 2010 to 2011. Euro Surveill 17 .

5. Kuo S, Chang S, Wang H (2012) Emergence of extensively drug-resistant Acinetobacter baumanniicomplex over 10 years, nationwide data from the Taiwan Surveillance of Antimicrobial Resistance TSAR program. BMC Infect Dis 12: $200-215$.

6. Sen B, Lewandowski K, Vaze N (2012) Characterization of carbapenemresistant MDR Acinetobacter baumanniiisolated from Philadelphia, PA United States. Infect Dis 827: $534-540$

7. Kempf M, Bakour S, Flaudrops C (2012) Rapid Detection of Carbapenem Resistance in Acinetobacter baumannii Using Matrix-Assisted Laser Desorption Ionization-Time of Flight Mass Spectrometry. PLoS One 72: 1-7.

8. Huang H, Yang ZL, Wu XM, Wang Y, Liu YJ, et al. (2012) Complete genome sequence of Acinetobacter baumannii MDR-TJ and insights into its mechanism of antibiotic resistance. J Antimicrob Chemother 67: 2825-2832.

9. de Souza Gusatti C, Bertholdo LM, Otton LM, Marchetti DP, Ferreira AE, et al. (2012) First occurrence of bla OXA-58 in Acinetobacter baumannii isolated from a clinical sample in Southern Brazil. Braz J Microbiol 43: 243-246.

10. Forbes BA, Sahm DF, weissfeld AS (2007) Baily and scott's diagnostic microbiology. 12th ed. Mosby Elsevire, Texas: 334-339.

11. Turton JF, Woodford N, Glover J, (2006) Identification of Acinetobacte baumanniiby detection of the blaOXA-51-like carbapenemase gene intrinsic to this species. J Clin Microbiol 44: 2974-2976.

12. Taherikalani M, Fatolahzadeh B, Emaneini M, Soroush S, Feizabadi MM (2009) Distribution of different carbapenem resistant clones of Acinetobacter baumannii in Tehran hospitals. New Microbiol 32: 265-271.
13. Hussein N, Al-Mathkhury H, Sabbah M (2013) Imipenem-Resistant Acinetobacter baumannii isolated from patients and hospitals environment in Baghdad. Iraqi J Sci 54: 803-812.

14. Bauer AW, Kirby WM, Sherris JC, Turck M (1966) Antibiotic susceptibility testing by a standardized single disk method. Am J Clin Pathol 45: 493-496.

15. Baron EJ, Finegold SM (1990) Bailey \& Scotts Diagnostic Microbiology. 8th ed. Mosby, Comp. Missouri.

16. CLSI (Clinical \& Laboratory Standards institute) (2013). Performance standard for antimicrobial susceptibility testing; Seventeenth informational supplement. M100-S23. 33.

17. Maniatis T, Fritsch E, Sambrook J (1982) Molecular Cloning, a Laboratory Manual. Cold Spring Harbor Laboratory, New York 545-546.

18. Bonnin RA, Ocampo-Sosa AA, Poirel L (2012) Biochemical and Genetic Characterization of Carbapenem-Hydrolyzing B-Lactamase OXA-229 from Acinetobacter bereziniae. Antimicrob Agents Chemother 56: 3923- 3927.

19. Lee Y, Kuo S, Chiang M (2012) Emergence of Carbapenem-Resistant Nonbaumannii Species of Acinetobacter Harboring a blaOXA-51-Like Gene That Is Intrinsic to A. baumannii. Antimicrob Agents Chemother 65: 1124-1127.

20. Mugnier PD, Poirel L, Naas T, Nordmann P (2010) Worldwide dissemination of the blaOXA-23 carbapenemase gene of Acinetobacter baumannii. Emerg Infect Dis 16: 35-40.

21. Niumsup PR, Boonkerd N, Tansawai U, Tiloklurs M (2009) Carbapenemresistant Acinetobacter baumannii producing OXA-23 in Thailand. Jpn J Infect Dis 62: $152-154$

22. Hujer KM, Hujer AM, Hulten EA (2006) Analysis of Antibiotic Resistance Genes in Multidrug-Resistant Acinetobacter sp. Isolates from Military and Civilian Patients Treated at the Walter Reed Army Medical Center. Antimicrob Agents Chemother 50: 4114-4123.

23. Corvec S, Caroff N, Espaze E (2003) AmpC cephalosporinase hyper production in Acinetobacter baumannii clinical strains. J Antimicrob Chemother 52: 629635

24. Zhong Q, Xu W, Wu Y, Xu H (2012) Clonal spread of carbapenem nonsusceptible Acinetobacter baumannii in an intensive care unit in a teaching hospital in China. Ann Lab Med 32: 413-419. 